\title{
MOTIVASI REMAJA DALAM MENGAMBIL KEPUTUSAN MEMILIH PENGAJIAN MAJLIS TAKLIM ASSHIFA DI ANJUN KARAWANG
}

\author{
${ }^{1}$ July Yuliawati \\ ${ }^{2}$ Neni Sumarni \\ ${ }^{3}$ Robby Fauji \\ july.yuliawati@ubpkarawang.ac.id,neni.sumarni@ubpkarawang.ac.id, \\ robby.fauji@ubpkarawang.ac.id
}

\begin{abstract}
Abstrak
Tujuan dilakukannya penelitian ini adalah untuk mengetahui motivasi remaja dalam mengambil keputusan memilih pengajian majlis taklim asshifa di anjun Karawang. Penelitian ini dilakukan di daerah anjun karawang. Jenis penelitian yang digunakan bersifat penjelasan (deskriptif) dengan pendekatan kuantitatif dengan jumlah populasi pada penelitian ini adalah 50 santri dengan sampel 50 santri. Data diperoleh dengan mengunakan kuesioner dan diolah oleh program spss 20. Analisis data pada penelitian ini menggunakan uji Validitas dan uji reliable, data mengunakan kuesioner yang sudah disebar utuk mengetahui apakah data tersebut valid dan reliable. Untuk kuesioner motivasi dihasilkan validitas dan reliablitias menghasilkan $r$ hitung $0.937>r$ tabel 0,2767 dengan nilai rentang cronbah alfa reabilitas sempurna yang artinya para santri sangat termotivasi untuk mengaji di pengajian majlis taklim asshifa, sedangkan untuk pengambilan keputusan dihasilkan uji validitas dan uji reabilitas $r$ hitung 0,953 $>\mathrm{r}$ tabel 0,2767 dengan nilai rentang cronbah alfa reabilitas sempurna yang artinya para remaja santri dalam mengambil keputusan tidak ada paksaan dari siapapun dalam memilih pengajian majlis taklim asshifa. Untuk pembinaan remaja seharusnya tidak hanya di sekitar wilayah anjun saja tetapi di seluruh wilayah kabupaten karawang dengan melibatkan seluruh lapisan masyarakat agar generasi muda baik remaja, dewasa lebih dekat dengan agama sehingga terhindar dari perbuatan yang merugikan dirinya maupun orang lain.
\end{abstract}

Kata Kunci : Motivasi , pengambilan keputusan, remaja, pengajian , majlis taklim .

\begin{abstract}
The purpose of this research is to determine the motivation of adolescents in making decisions to choose the majlis taklim asshifa recitation in anjun Karawang. This research was conducted in the Anjun Karawang area. The type of research used is descriptive (descriptive) with a quantitative approach with the total population in this study is 50 students with a sample of 50 students.
\end{abstract}


Data obtained by using a questionnaire and processed by the SPSS 20 program. Analysis of the data in this study used the validity test and reliable test, the data used a questionnaire that had been distributed to find out whether the data was valid and reliable. For the motivation questionnaire, the validity and reliability of the resulting $r$ count was 0.937> $r$ table 0.2767 with the value of the cronbah alpha range of perfect reliability, which meant that the students were very motivated to recite the recitation in the majlis taklim asshifa, Meanwhile, for decision making, the validity and reliability tests of $r$ count was $0.953>r$ table 0.2767 with the value of the perfect cronbah alpha reliability range, which means that young students in making decisions are not compelled by anyone in choosing the majlis taklim asshifa recitation. For the development of adolescents, it should not only be around the Anjun area but in all areas of Karawang Regency by involving all levels of society so that the young generation, both adolescents and adults, are closer to religion so that they avoid actions that harm themselves and others.

Keywords: Motivation, decision making, adolescents, majlis taklim.

\section{PENDAHULUAN}

Pemahaman ilmu agama sangat penting bagi remaja di era milenial saat ini. Selain karena memang dasar dari agama Islam untuk dapat melakukan kewajiban secara syariat, namun juga pembentukan karakter harus dapat disesuaikan dengan pribadi dan lingkungan. Sebab tak jarang ada remaja yang terjerumus ke dalam hal negative. Disinilah peran orang tua dan lingkungan yang dapat membentuk nya secara pribadi. Untuk itu jika peran orang tua tidak dapat membimbing mereka di dalam agama, maka banyak orang tua untuk menyekolahkan anaknya untuk sekolah yang berbasis agama islam atau mengikut sertakan mereka ke dalam pengajian baik pengajain yang terwadah dalam majlis, maupun pengajian yang terwadah dalam kajian di sekolah umum.

Disekolah pembelajaran agama hanya sebatas kurikulum belum menjadikan dasar bahwa agama sebagai tiang untuk pendidikan karakter. Fenomena yang terjadi saat ini pendidikan agama hanya sebagai melengkapi kurikulum saja, belum pada pengertian syariat islam untuk dijalankan sebagai kewajiban muslim. Banyak remaja yang pada akhir nya melanggar kewajiban syariat islamnya, seperti pergaulan bebas, narkoba, kenakalan remaja bahkan 
sampai kriminalitas.

Menurut data publikasi statistic kriminal 2019, menyajikan gambaran umum mengenai tingkat dan perkembangan kriminalitas di Indonesia selama periode 2016-2018. Informasi yang disajikan mencakup tiga pendekatan utama statistic criminal yaitu : Pendekatan Pelaku, Korban, dan Kewilayahan. Data yang disajikan diperoleh dari sumber utama statistic criminal yaitu : (1) Data Berbasis regristrasi ( administrative base data ) yaitu, data criminal yang dihimpun oleh kepolisian Republik Indonesia ( POLRI). (2) Data Berbasi Survey ( survey base data ) yaitu, data criminal yang bersumber dari survey social ekonomi nasional ( SUSENAS ) dan pendataan potensi desa ( PODES ) yang dihasilkan oleh Badan Pusat Statistik ( BPS ).

Data registrasi POLRI mencatat bahwa tingkat kejahatan atau Crime Ret selama periode tahun 2016-2018 mengalami penurunan. Tingkat resiko terkena tindak kejahatan setiap seratus ribu penduduk pada tahun 2015 sekitar 140, menjadi 129 pada tahun 2017, dan menurun menjadi 113 pada tahun 2018. Data SUSENAS yang menggambarkan persentasi penduduk menjadi korban kejahatan di Indonesia selama periode tahun 2016-2018 juga memperlihatkan pola yang fluktuatif.

Persentase penduduk korban kejahatan di Indonesia mengalami penurunan dari 1,22 \% pada tahun 2016 menjadi 1,08\% pada tahun 2017, dan meningkat menjadi 1,11 \% pada tahun 2018. Berdasarkan data PODES selama tahun 20112018, jumlah desa atau kelurahan yang menjadi ajang konflik massal cenderung meningkat, dari sekitar 2500 desa pada tahun 2011 menjadi sekitar 2700 desa atau kelurahan pada tahun 2014, dan kembali meningkat menjadi sekitar 3100 desa atau kelurahan pada tahun 2018.

Berdasarkan fenomena tersebut, untuk mencegah para remaja melakukan tindakan kriminalitas perlu adanya benteng pertahanan dalam pola piker mereka untuk tidak bertindak seperti itu. Salah satu nya adalah dengan pendidikan karakter dan pendidikan agama yang sangat kuat. Salah satu wadah untuk pembentukan karakter dan pemahaman agama yang sesuai syariat nya maka para remaja diharapkan dapat belajar di berbagai lembaga, jika pada lingkup keluarga 
atau orangtua tidak mendapatkan hal tersebut. Sehingga kecenderungan orangtua untuk menyekolahkan mereka atau memasukkan mereka ikut serta pengajian diberbagai majlis.

Motivasi adalah suatu proses yang mendorong atau mempengaruhi seseorang untuk mendapatkan atau mencapai yang diinginkannya, baik itu secara positif maupun negative. Motivasi bisa di dapat dari motivasi internal dan motivasi eksternal. Yang mana motivasi internal tumbuh dari dalam diri sendiri tanpa di pengaruhi oleh orang lain, sedangkan motivasi eksternal datang dari luar diri seseorang dengan harapan dapat mencapai suatu tujuan yang dapat menguntungkan dirinya.

Keputusan memiliki arti pilihan dari beberapa kemungkinan merupakan hasil proses pemikiran yang berupa pemilihan satu diantara beberapa alternative yang dapat digunakan untuk memecahkan masalah yang dihadapinya. Menurut Terry, pengambilan keputusan adalah pemilihan alternative atau kelakuan tertentu dari dua atau lebih alternative yang ada, bila seseorang gagal menguasai bidang tersebut maka muncullah beragam masalah dalam pencapaian tujuan dapat dihubungkan ketidak mampuan dalam melakukan proses pengambilan keputusan dalam menentukan pilihan yang tepat.

Berdasarkan teori diatas dalam pemilihan remaja untuk mengikuti majlis taklim Asshifa dibutuhkan motivasi dan pengambilan keputusan yang tepat. Motivasi dalam memilih didasari oleh beberapa factor. Seperti kebutuhan psikological, rasa aman, kebutuhan akan social, kebutuhan akan harga diri dan aktualisasi diri. Sedangkan dasar pengambilan keputusan didasari oleh pengambilan keputusan intuisi, pengambilan keputusan rasional, pengambilan keputusan berdasarkan fakta dan pengambilan keputusan berdasarkan pengalaman, berdasarkan wewenang.

Berdasarkan uraian diatas penulis tertarik mengambil judul dalam penelitian yaitu “ MOTIVASI REMAJA DALAM MENGAMBIL KEPUTUSAN MEMILIH PENGAJIAN MAJLIS TAKLIM ASSHIFA DI ANJUN KARAWANG “. 
Dari beberapa permasalahan yang telah dipaparkan diatas, maka penulis mencoba untuk melakukan penelitian pada remaja di daerah Anjun Karawang, maka penelitian ini akan berfokus pada : "Apakah motivasi remaja dalam mengambil keputusan memilih pengajian majlis taklim Asshifa di Anjun Karawang?"

Tujuan dari penelitian ini adalah sebagai berikut : Untuk mengetahui motivasi remaja dalam mengambil keputusan memilih pengajian majlis Asshifa di Anjun Karawang.

Urgensi penelitian ini dapat memberikan kepentingan terhadap mata kuliah manajemen sumber daya manusia, tentang motivasi dan pengambilan keputusan. Penelitian diharapkan dapat memberikan kontribusi positif bagi penulis khususnya dan masyarakat, remaja serta para mahasiswa secara umum. Penelitian ini diharapkan mampu memberikan nilai lebih sebagai daya saing dan keunggulan pada perguruan tinggi dengan menciptakan berbagai macam penelitian baik secara keilmuan maupun kekinian yang di sesuaikan dengan kondisi saat ini. Sehingga akan dapat meningkatkan pertumbuhan perusahaan dalam hal ini pihak Universitas Buana Perjuangan Karawang, untuk meningkatkan kualitas kinerja baik para dosen, manajemen atau organisasi secara keseluruhan. Yang pada akhirnya bertujuan untuk dapat memuaskan para mahasiswa dan mampu menarik mahasiswa baru sebanyak mungkin.

Objek dalam penelitian ini yaitu para remaja yang berada di daerah Anjun Karawang. Populasi dalam penelitian ini adalah para remaja yang berada di daerah Anjun Karawang. Sampel dalam penelitian ini adalah remaja daerah Anjun diambil sebanyak 50 orang.

Sumber data yang dibutuhkan dalam penelitian ini atau data yang dikumpulkan di lapangan meliputi : Data Primer,yaitu data yang dihasilkan dari jawaban angket atau kuisioner, dan wawancara. Data Sekunder, yaitu data tentang keadaan umum para remaja yang berada di daerah Anjun Karawang. Data ini diperoleh dari dokumentasi dan studi pustaka.

Alat ukur data primer bersifat kualitatif, dilakukan dengan menggunakan 
skala likert yang kemudian di transformasikan menjadi kuantitatif dengan menggunakan empat jenjang yaitu dengan angka skor yang bernilai mulai dari 1 sampai dengan 4 dan data akan berubah menjadi kuantitatif. Dengan menggunakan program SPSS.20.

Pengolahan uji validitas dan reliabilitas dilakukan dengan menggunakan program SPSS. Uji validitas yang dilakukan pada penelitian ini adalah validitas internal yaitu menguji kesesuaian antara bagian-bagian instrument dengan instrument keseluruhan. Sedangkan uji reliabilitas yang dilakukan pada penelitian ini yaitu uji reliabilitas internal dengan menganalisis data dari satu kali pengetesan atau pengujian hasil kuesioner yang diisi oleh responden.

Teknik Pengumpulan Data Observasi : Metode dimana peneliti mengamati langsung objek yang diteliti.( Kriyantoro , 2006 ) dan (Arikunto, 2010) Interview : sesuai dengan pengertian, interview yang memiliki pengertian sebagai teknik pengumpulan data dengan cara pertukaran verbal tatap muka yang dilakukan oleh seorang pewawancara terhadap respondennya. Pewawancara berupaya untuk memperoleh informasi atau ungkapan - ungkapan pendapat, serta keyakinan dari subjek penelitian .

Penelitian ini menggunakan metode deskriptif yaitu metode dimana prosedur pemecahan masalah yang diselidiki dengan menggambarkan atau melukiskan keadaan objek penelitian pada saat sekarang berdasarkan fakta fakta yang tampak atau sebagaimana adanya, yaitu dengan melihat kasus yang berkembang saat ini ( Nawawi \& Matini, 1996 - 27 ). Penelitian ini menggunakan kualitatif yang memiliki relasi dengan analisis data visual dan data verbal yang merefleksikan pengalaman.

Analisis data adalah proses mengatur urutan data, mengorganisasikannya ke dalam suatu pola, kategori, dan satuan uraian data. Kegiatan analisis atau analisis data merupakan upaya mencari data secara sistematis dari data catatan hasil observasi, wawancara, dan lainnya untuk meningkatkan pemahaman peneliti tentang kasus yang diteliti dan mengkajinya sebagai temuan data yang valid diperoleh dengan penyederhanaan hasil perolehan data yang dilakukan dengan model interactive yang disusun secara terinci dan sistematis, yaitu 
langkah - langkah berikut :

1. Reduksi data, merupakan suatu proses dimana data yang diperoleh dari lapangan tersebut dilakukan reduksi, dirangkum, dipilih hal - hal yang pokok, dan difokuskan pada hal - hal yang penting, serta disusun secara sistematis dengan tujuan agar data tersebut menjadi lebih mudah dipahami dan dikendalikan.

2. Display data merupakan tampilan atau laporan yang merupakan informasi yang diperoleh sebagai hasil reduksi data yang memungkinkan adanya penarikan kesimpulan dan pengambilan tindakan.

3. Penarikan kesimpulan / verifikasi, dalam penelitian kualitatif, penarikan kesimpulan telah dilakukan sejak penelitian itu dimulai dimana peneliti mencari makna dari data yang dikumpulkannya dan melakukan penarikan kesimpulan.

Tahapan penelitian ini adalah : pertama penulis melakukan observasi dengan menyebarkan angket dan interview ke sampel penelitian kemudian mengukur seberapa banyak sampel yang melakukan pemilihan motivasi dan pengambilan keputusan .

Tabel 1 Kerangka Pikir Metodologis Motivasi Remaja dalam mengambil keputusan memilih Pengajian Majlis Taklim Asshifa di Anjun Karawang.

\begin{tabular}{|l|l|}
\hline Motivasi Remaja Anjun & Majlis Taklim Asshifa \\
\hline
\end{tabular}

Gambar.1 Kerangka Pemikiran

Hasil Pengujian Validitas dan Reliabilitas

\section{Uji Validitas}

Dalam menentukan valid tidaknya data dilakukan dengan melihat hasil dari korelasi ( nilai r ) setiap item data tersebut, dengan kriteria sebagai berikut : 
- $\quad$ Jika $r$ hitung positif, serta $r$ hitung $>r$ table, maka butir atau variable tersebut valid. Hasil dari uji validitas dan reliabilitas dinyatakan bahwa semua data dan item pertanyaan semuanya valid dan reliable.

- $\quad$ Jika $r$ hitung negative, dan $r$ hitung $<\mathrm{r}$ table, maka butir atau variable tersebut tidak valid.

Uji validitas yang dilakukan adalah dengan menguji semua variable pertanyaan yang terbagi kedalam empat kelompok kuisioer terhadap responden. Hasil perhitungan validitas menggunakan program SPSS dapat dilihat pada table dibawah ini :

Tabel 2 Hasil Uji Validitas Motivasi

\begin{tabular}{|l|r|r|r|r|}
\hline \multicolumn{7}{|c|}{ Item-Total Statistics } \\
\hline & $\begin{array}{l}\text { Scale Mean if } \\
\text { Item Deleted }\end{array}$ & $\begin{array}{c}\text { Scale Variance } \\
\text { if Item Deleted }\end{array}$ & $\begin{array}{c}\text { Corrected Item- } \\
\text { Total } \\
\text { Correlation }\end{array}$ & $\begin{array}{c}\text { Cronbach's } \\
\text { Alpha if Item } \\
\text { Deleted }\end{array}$ \\
\hline Item_1 & 29.70 & 17.597 & .923 & .947 \\
\hline Item_2 & 30.30 & 15.734 & .806 & .929 \\
\hline Item_3 & 30.30 & 15.734 & .806 & .929 \\
\hline Item_4 & 29.90 & 15.403 & .787 & .929 \\
\hline Item_5 & 30.10 & 13.541 & .742 & .937 \\
\hline Item_6 & 30.50 & 13.707 & .912 & .922 \\
\hline Item_7 & 30.30 & 15.734 & .806 & .929 \\
\hline Item_8 & 29.90 & 15.403 & .787 & .929 \\
\hline Item_9 & 30.50 & 13.707 & .912 & .922 \\
\hline Item_10 & 30.30 & 15.734 & .806 & .929 \\
\hline
\end{tabular}

Keterangan :

$$
\begin{array}{ll}
\mathrm{N}=50 & \alpha=5 \%(0.05) \\
\mathrm{df}=\mathrm{n}-\mathrm{k}-1 \mathrm{df}=\mathrm{n}-2 & \mathrm{r} \text { table }=0.2787 \\
\mathrm{df}=50-2 & \mathrm{df}=48
\end{array}
$$

Kesimpulan :

Berdasarkan hasil uji validitas motivasi tersebut diatas dinyatakan semua data adalah valid karena semua memiliki $r$ hasil di atas $r$ table $(r$ table $=0.2787$ dengan tingkat signifikansi $5 \%$ dan $\mathrm{df}=48$ ). 


\section{Uji Reliabilitas}

Apabila data dinyatakan valid, maka nilai alpha dari pengujian tersebut digunakan untuk mengetahui reliabilitas data dengan kriteria sebagai berikut :

- $\quad$ Jika $\mathrm{r}$ alpha positif dan $\mathrm{r}$ alpha $>\mathrm{r}$ table, maka butir atau variable tersebut reliable.

- Jika $\mathrm{r}$ alpha negative dan $\mathrm{r}$ alpha $<\mathrm{r}$ table, maka butir atau variable tersebut tidak reliable.

Hasil pengujian reliabilitas diperoleh :

Tabel 3 Hasil Uji Reliabilitas Motivasi

\begin{tabular}{|r|r|}
\hline \multicolumn{2}{|c|}{ Reliability Statistics } \\
\hline $\begin{array}{c}\text { Cronbach's } \\
\text { Alpha }\end{array}$ & N of Items \\
\hline .937 & 10 \\
\hline
\end{tabular}

Kesimpulan :

Untuk mengukur suatu data reliable maka perlu adanya rentang nilai alpha cronbach's yaitu :
a. Alpha $<0,50$ reliabilitas rendah
b. $\quad 0,50<$ alpha $<0,70$ reliabiltas moderat
c. Alpha $>0,70$ reliable mencukupi (sufficient reliabilily)
d. Alpha $>0,80$ maka reabilitas kuat
e. Alpha $>0,90$ maka reabilitas sempurna

Berdasarkan dari hasil uji tabel realibiltas statistic untuk motivasi menunjukkan hasil analisis dari uji reabilitas dengan Cronbach's Alpha sebesar 0,937 dari 10 item variabel. Nilai rentang alpha yang dihasilkan sebesar 0,937 adalah nilai sempurna . Data tersebut memiliki $r$ alpha positif sebesar 0,937 > r tabel sebesar 0,2767, maka untuk seluruh kuesiner ini dinyatakan reliable

3. Uji vaiditas pegambilan keputusan

Tabel 4 Hasil Uji Validitas Pengambilan Keputusan 
Item-Total Statistics

\begin{tabular}{|l|r|r|r|r|}
\hline & $\begin{array}{c}\text { Scale Mean if } \\
\text { Item Deleted }\end{array}$ & $\begin{array}{c}\text { Scale Variance } \\
\text { if Item Deleted }\end{array}$ & $\begin{array}{c}\text { Corrected Item- } \\
\text { Total } \\
\text { Correlation }\end{array}$ & $\begin{array}{c}\text { Cronbach's } \\
\text { Alpha if Item } \\
\text { Deleted }\end{array}$ \\
\hline item_1 & 32.6600 & 12.678 & .952 & .941 \\
item_2 & 32.9200 & 13.300 & .631 & .955 \\
item_3 & 32.9200 & 13.300 & .631 & .955 \\
item_4 & 32.6600 & 12.678 & .952 & .941 \\
item_5 & 32.6800 & 12.712 & .915 & .943 \\
item_6 & 32.7800 & 13.032 & .736 & .950 \\
item_7 & 32.7200 & 12.777 & .854 & .945 \\
item_8 & 32.8000 & 13.061 & .719 & .951 \\
item_9 & 32.7000 & 12.786 & .869 & .945 \\
item_10 & 32.7600 & 12.962 & .768 & .949 \\
\hline
\end{tabular}

\section{Keterangan :}

$$
\begin{array}{ll}
\mathrm{N}=50 & \alpha=5 \%(0.05) \\
\mathrm{df}=\mathrm{n}-\mathrm{k}-1 \mathrm{df}=\mathrm{n}-2 & \mathrm{r} \text { table }=0.2787 \\
\mathrm{df}=50-2 & \mathrm{df}=48
\end{array}
$$

\section{Kesimpulan :}

Berdasarkan hasil uji validitas pengambilan keputusan tersebut diatas dinyatakan semua data adalah valid karena semua memiliki $r$ hasil di atas $r$ table $(\mathrm{r}$ table $=0.2787$ dengan tingkat signifikansi $5 \%$ dan $\mathrm{df}=48)$.

\section{Uji Reliabilitas Pengambilan Keputusan}

Apabila data dinyatakan valid, maka nilai alpha dari pengujian tersebut digunakan untuk mengetahui reliabilitas data dengan kriteria sebagai berikut :

- Jika $\mathrm{r}$ alpha positif dan $\mathrm{r}$ alpha $>\mathrm{r}$ table, maka butir atau variable tersebut reliable.

- Jika $\mathrm{r}$ alpha negative dan $\mathrm{r}$ alpha $<\mathrm{r}$ table, maka butir atau variable tersebut tidak reliable.

Hasil pengujian reliabilitas diperoleh : 
Tabel 5 Hasil Uji Reabilitas Pengambilan Keputusan

Reliability Statistics

\begin{tabular}{|r|r|}
\hline $\begin{array}{c}\text { Cronbach's } \\
\text { Alpha }\end{array}$ & N of Items \\
\hline .953 & 10 \\
\hline
\end{tabular}

\section{Kesimpulan :}

Untuk mengukur suatu data reliable maka perlu adanya rentang nilai alpha cronbach's yaitu :
a. Alpha $<0,50$ reliabilitas rendah
b. $\quad 0,50<$ alpha $<0,70$ reliabiltas moderat
c. Alpha $>0,70$ reliable mencukupi (sufficient reliabilily)
d. Alpha $>0,80$ maka reabilitas kuat
e. Alpha $>0,90$ maka reabilitas sempurna

Berdasarkan dari hasil uji tabel realibiltas statistic untuk pengambilan keputusan menunjukkan hasil analisis dari uji reabilitas dengan Cronbach's Alpha sebesar 0,953 dari 10 item variabel. Nilai rentang alpha yang dihasilkan sebesar 0,953 adalah nilai sempurna . Data tersebut memiliki $r$ alpha positif sebesar $0,953>\mathrm{r}$ tabel sebesar 0,2767, maka untuk seluruh kuesiner ini dinyatakan reliable.

\section{Gambaran Umum Remaja Di Wilayah Anjun Karawang}

Anjun merupakan desa yang terletak di kelurahan Karawang Kulon, Kecamatan Karawang Barat, Kabupaten Karawang. Desa Anjun terbagi kedalam tiga wilayah, yaitu Anjun Kidul, Anjun Kaler dan Anjun Kanoman. Dimana pada wilayah Anjun yang penulis teliti adalah remaja yang ikut pengajian di majlis ta'lim asshifa. Hal ini sesuai yang disampaikan oleh bapak Ato selaku ketua RW 012.

Dalam penelitian ini penulis melakukan penelitian di wilayah Anjun , dengan mengambil responden 50 remaja yang berusia 13 sd 22 tahun . 


\section{Gambaran Umum Majlis Taklim Asshifa di Wilayah Anjun Karawang}

Majlis taklim Asshifa didirikan tahun 2006 oleh bapak H. M. Yaya Sumardi Atmadja.S.Ag. Yang berada di wilayah Anjun Kaler, tepatnya Jl. Singasari belakang masjid Al-Hikmah Anjun Karawang. Berawal dari rasa keprihatinan terhadap para remaja Anjun yang saat itu belum ada wadah atau naungan keagamaan, maka beliau selaku salah satu warga anjun lulusan dari IAIN Sunan Gunung Djati yang memiliki rasa empati serta pemahaman keagamaan yang mendasari pola pikir nya akhirnya mencoba untuk mengajak para remaja tersebut berkumpul dirumahnya. Pada awalnya pengajian ini hanya dilakukan di malam minggu untuk menghindari para remaja berkumpul tidak jelas di malam minggu. Karena memang pada saat itu keprihatinnan remaja yang melakukan tindakan negative seperti balap motor liar, dan narkoba sangat tinggi. Beliau mencoba pendekatan psikologis berupa pemahaman tentang pentingnya sholat. Jadi awal mula proses pengajian pun hanya cerita dan mendengarkan keluhan - keluhan para remaja tersebut.

Seiring berjalannya waktu, proses pengajaran pada pengajian majlis taklim Asshifa kemudian mengalami perkembangan dan kemajuan. Tidak hanya pada jumlah dan pembagian pengajian namun juga metode, pengajar dan macam pengajiannya. Awal berdirinya pengajian hanya berorientasi pada remaja, namun setelah sekian tahun selama kurang lebih 5 tahun berjalan, berubah dengan mengkelompokkan jenis usia pengajian, dari usia 5-10 tahun atau usia SD dibagi menjadi 4 kelompok dengan kesesuaian dari minat dan keinginan santrinya. Misalnya saja yang ingin memperdalam membaca Al-Quran, Tilawah dan Marawis. Ada juga yang pengajian jenis ceramah dan sharing keilmuan agama Islam. Dengan jadwal mengaji setiap hari yang sehabis maghrib.Untuk tingkat usia 11-22 tahun, terbagi kedalam empat bagian yakni di malam minggu khusus untuk kajian dan ceramah keIslaman dan juga wejangan - wejangan yang memang diperuntukkan sebagai bekal para remaja agar tidak terjerumus kedalam peregaulan negative. Kemudian untuk hari - hari biasa diisi dengan mengaji Al-Quran, Marawis dan rutinnan untuk jiarah ke tempat tempat Islami. 
Untuk para ibu Rumah Tangga juga ada waktu khususnya yaitu di hari Selasa dan Kamis, dengan metode yang berbeda. Untuk Hari Selasa pengajian berjenis mengaji Al-Quran untuk Hari Kamis ceramah dan kajian baik tafsir, hadist dan kajian Islam lainnya.

Berbagai macam kegiatan pendukung lainnya banyak dilakukan oleh pengajian Asshifa, mengikuti lomba marawis yang selalu memenangkan juara baik tingkat kabupaten bahkan propoinsi, kemudian kegiatan rutinna seperti Muharram, dengan Pawai Obor nya, Maulid Nabi, Razab, 17 Agustus juga tidak luput dari Asshifa untuk merayakan nya yang tentunya dilakukan dengan cara keIslaman.

\section{Hasil Riset Peneltian}

Berdasarkan hasil pengumpulan data yang dilakukan melalui penyebaran angket kepada 50 responden remaja Anjun Karawang, dimana jawaban responden yang telah penulis terima ditemukan informasi tentang tanggapan pada masing-masing pertanyaan. Untuk masing-masing pertanyaan angket diperoleh hasil sebagai berikut :

1. Pertanyaan Tentang Motivasi

- $\quad 42$ responden menjawab sangat setuju dan 8 orang menjawab setuju bahwa para pengajar Asshifa kompeten dalam bidangnya, sehingga termotivasi untuk mengaji di Asshifa.

- 17 responden sangat setuju dan 33 responden setuju bahwa seluruh anggota remaja mempunyai rasa memiliki terhadap pengajian majlis ta'lim Asshifa menjadikan motivasi para remaja Anjun memilih Asshifa sebagai tempat mengaji.

- $\quad 17$ responden sangat setuju dan 33 responden setuju lingkungan kondusif pada pengajian Asshifa menjadikan motivasi para remaja Anjun memilih Asshifa sebagai tempat mengaji.

- 36 responden sangat setuju dan 14 responden setuju terjamin keamanannya mengaji di Asshifa menjadikan motivasi para remaja Anjun memilih Asshifa sebagai tempat mengaji. 
- $\quad 36$ responden sangat setuju dan 8 responden setuju dan 6 yang tidak setuju , para santi dapat berkomunikasi dengan para pengajar majlis ta'lim Asshifa menjadikan motivasi para remaja Anjun memilih Asshifa sebagai tempat mengaji.

- $\quad 27$ responden sangat setuju dan 17 responden setuju dan 6 yang tidak setuju, para santi dapat bersosialisasi dengan sesama santri lainnya dengan baik dan beretika, menjadikan motivasi para remaja Anjun memilih Asshifa sebagai tempat mengaji.

- $\quad 37$ responden sangat setuju dan 13 responden setuju, para santi dapat mendapatkan penghargaan berupa peringkat terbaik dan hadiah dari para pengajar, menjadikan motivasi para remaja Anjun memilih Asshifa sebagai tempat mengaji.

- $\quad 36$ responden sangat setuju dan 14 responden setuju, para santi yang berprestasi mendapatkan kenaikan tingkat serta pujian dari pimpinan majlis ta'lim ashifa. , menjadikan motivasi para remaja Anjun memilih Asshifa sebagai tempat mengaji.

- $\quad 27$ responden sangat setuju dan 17 responden setuju, Persaingan yang sehat antar santriwan dan santriwati di majlis ta'lim ashifa., menjadikan motivasi para remaja Anjun memilih Asshifa sebagai tempat mengaji.

- $\quad 33$ responden sangat setuju dan 17 responden setuju, Seluruh tim pengajar oleh pimpinan majlis ta'lim dituntut untuk lebih kreativ dan inovatif dalam mengajar para santri, menjadikan motivasi para remaja Anjun memilih Asshifa sebagai tempat mengaji.

2. Pertanyaan Tentang Pengambilan Keputusan

- $\quad 37$ responden sangat setuju dan 13 responden setuju menjawab bahwa mereka memutuskan sendiri keinginan untuk mengaji di majlis Taklim Asshifa.

- $\quad 24$ responden sangat setuju dan 13 responden setuju dan 13 responden tidak setuju menjawab bahwa waktu mengaji disesuaikan dengan waktu yang di inginkan para santri sendiri untuk mengaji di majlis Taklim Asshifa.

- $\quad 24$ responden sangat setuju dan 26 responden setuju menjawab bahwa mereka mengambil keputusan sangat rasional dalam memilih pengajian majlis 
taklim asshifa .

- $\quad 37$ responden sangat setuju dan 13 responden setuju menjawab bahwa mereka memutuskan karena pengajian asshifa lebih kekinian dan lebih milenial dalam mengambil hati para santri .

- $\quad 36$ responden sangat setuju dan 14 responden setuju menjawab bahwa majlis taklim ashifa tidak bertentangan dengan hukum di Indonesia dan syariat islam.

- $\quad 33$ responden sangat setuju dan 17 responden setuju menjawab bahwa pengajian majlis taklim asshifa lebih terbuka dan lebih kooperatif dalam aspek pengajaran dan membangun karakter para santri .

- $\quad 37$ responden sangat setuju dan 13 responden setuju menjawab bahwa di tempat pengajian yang dulu kurang memberikan apresiasi dan terlalu kaku.

- $\quad 37$ responden sangat setuju dan 13 responden setuju menjawab bahwa karena di dasari oleh keinginan untuk belajar lebih baik dan mudah untuk di ikuti untuk mengaji di majlis Taklim Asshifa.

- $\quad 35$ responden sangat setuju dan 15 responden setuju menjawab bahwa memilih pengajian majlis ta'lim ashifa adalah hak pribadi dari masing masing santri untuk mengaji di majlis Taklim Asshifa.

- $\quad 32$ responden sangat setuju dan 18 responden setuju menjawab bahwa mereka memutuskan sendiri keinginan untuk mengaji di majlis Taklim Asshifa.

\section{KESIMPULAN DAN SARAN}

\section{Kesimpulan}

a. Dari hasil yang pengolahan data validitas dan reabilitas motivasi dapat disimpulkan bahwa berdasarkan hasil uji validitas motivasi tersebut diatas dinyatakan semua data adalah valid karena semua memiliki $r$ hitung di atas $\mathrm{r}$ table $(\mathrm{r}$ table $=0.2787$ dengan tingkat signifikansi $5 \%$ dan $\mathrm{df}=48)$. Sedangkan untuk reabilitas motivasi berdasarkan dari hasil uji tabel realibiltas statistic untuk motivasi menunjukkan hasil analisis dari uji reabilitas dengan Cronbach's Alpha 
sebesar 0,937 dari 10 item variabel. Nilai rentang alpha yang dihasilkan sebesar 0,937 adalah nilai sempurna . Data tersebut memiliki $r$ alpha positif sebesar $0,937>\mathrm{r}$ tabel sebesar 0,2767 , maka untuk seluruh kuesiner ini dinyatakan reliable.

Artinya seluruh remaja santri sangat termotivasi untuk mengaji dipengajian majlis taklim asshifa.

b. Berdasarkan hasil uji validitas pengambilan keputusan tersebut diatas dinyatakan semua data adalah valid karena semua memiliki $r$ hitung di atas $r$ table $(\mathrm{r}$ table $=0.2787$ dengan tingkat signifikansi $5 \% \mathrm{dan} \mathrm{df}=48)$. Sedangkan untuk reabilitas pengambilan keputusan Berdasarkan dari hasil uji tabel realibiltas statistic untuk pengambilan keputusan menunjukkan hasil analisis dari uji reabilitas dengan Cronbach's Alpha sebesar 0,953 dari 10 item variabel. Nilai rentang alpha yang dihasilkan sebesar 0,953 adalah nilai sempurna . Data tersebut memiliki $r$ alpha positif sebesar $0,953>r$ tabel sebesar 0,2767, maka untuk seluruh kuesiner ini dinyatakan reliable.

Artinya seluruh remaja santri dalam memilih berdasarkan keputusan sendiri tanpa paksaan dari siapapun untuk mengaji dipengajian majlis taklim asshifa.

\section{Saran}

Untuk pembinaan remaja seharusnya tidak hanya di sekitar wilayah anjun saja tetapi di seluruh wilayah kabupaten karawang dengan melibatkan seluruh lapisan masyarakat agar generasi muda baik remaja, dewasa lebih dekat dengan agama sehingga terhindar dari perbuatan yang merugikan dirinya maupun orang lain. 


\section{DAFTAR PUSTAKA}

A.A Anwar Prabu Mangkune, 2011, Manajemen Sumbber Daya Manusia Perusahaan, Remaja Rosdakarya, Bandung .

Abdul Jamil dkk, Pedoman Majelis Ta'lim, (Jakarta: Direktorat Penerangan Agama Islam, 2012

Arikunto, Suharsimi, Prosedur Penelitian Suatu Pendekatan Praktik, Rineka Cipta, Jakarta, 2010.

George R.Terry dan Brinckloe. (2010). Dasar-Dasar Pengambilan Keputusan [.ppt]. https://ismaan.wordpress.com/2020/05/19/defenisi-dandasar-pengambilan- keputusan/.

Hasibuan , Malayu, SP, 208, Manajemen Sumber Daya Manusia , Edisi Revisi, PT Bumi Aksara, Jakarta.

Hasibuan, Malayu S.P, 2013, Manajemen Sumber Daya Manusia, Edisi Revisi, PT. Bumi Aksara, Jakarta.

Hadari Nawawi dan Mini Martini, Penelitian Terapan, Yogyakarta: Gajah Mada University Press, 1996.

Herminarto Sofyan \& Hamzah B.Uno. (2012). Teori Motivasi dan Penerapannya dalam Penelitian. Yogyakarta: UNY Press.

Helmawati, Pendidikan Nasional dan Optimalisasi Majelis Ta'lim: Peran Aktif Majelis Ta'lim Meningkatkan Mutu Pendidikan, (Jakarta: Rineka Cipta, 2013).

Kriyantono, Rahmat “, Teknik Praktids Komunikasi “, Kencana, Jakarta, 2006

M. Manullang, 2012, Dasar-dasar Manajemen Bagi Pimpinan Perusahaan, Jakarta, Gajah Mada Press.

Muhsin MK, Manajemen Majelis Ta'lim: Petunjuk Praktis Pengelolaan dan Pembentukannya, (Jakarta: Pustaka Intermasa, 2009).

Sugiono, 2013, Metode Penelitian Kuantitati dan Kualitatif dan R \& D, Penerbit Alfabeta, Bandung.

T. Hani Handoko, 2009 , Manajemen Personalia dan Sumber Daya Manusia, BPFE, Yogyakarta.

Tuti Alawiyah, Strategi Dakwah di Lingkungan Majelis Taklim (Cet. I; Bandung: Mizan,1997) 
Puslitbang Kehidupan Keagamaan, Peningkatan Peran Serta Masyarakat dalam Pendalaman Ajaran Agama melalui Majelis Taklim, (Jakarta: Puslitbang Kehidupan Keagamaan, 2007),

Wikipedia bahasa Indonesia : id.wikipedia.org/wiki/kenakalan-remaja/remaja di akses 10 Oktober 2020. 